\title{
Community Knowledge and Practice Regarding Ebola Prevention in FCT, Abuja
}

\author{
Helen Adamu ${ }^{1,5}$, , Samuel Ogundare ${ }^{2}$, ThankGod Emmanuel Onyiche ${ }^{3}$, Magdalene Nanvene ${ }^{4}$, \\ Babajide Daini $^{5}$, Modupe Fasina ${ }^{6}$ \\ ${ }^{1}$ Center for Clinical Care and Clinical Research, Jahi, Abuja, Nigeria \\ ${ }^{2}$ Department of Medical Microbiology, Faculty of Health Sciences, University of Pretoria, Pretoria, South Africa \\ ${ }^{3}$ Department of Veterinary Parasitology and Entomology, Faculty of Veterinary Medicine, University of Maiduguri, Borno, Nigeria \\ ${ }^{4}$ Department of Microbiology, Faculty of Veterinary Medicine, Ahmadu Bello University, Kaduna, Nigeria \\ ${ }^{5}$ Department of Epidemiology and Medical Statistics, Faculty of Public Health, College of Medicine, University of Ibadan, Oyo, Nigeria \\ ${ }^{6}$ Department of Nursing Science, Faculty of Health Sciences, University of Pretoria, Pretoria, South Africa
}

Email address:

Adamuhelen66@yahoo.com (H. Adamu)

${ }^{*}$ Corresponding author

\section{To cite this article:}

Helen Adamu, Samuel Ogundare, ThankGod Emmanuel Onyiche, Magdalene Nanvene, Babajide Daini, Modupe Fasina. Community Knowledge and Practice Regarding Ebola Prevention in FCT, Abuja. Central African Journal of Public Health.

Vol. 6, No. 3, 2020, pp. 144-153. doi: 10.11648/j.cajph.20200603.16

Received: March 6, 2020; Accepted: March 26, 2020; Published: April 23, 2020

\begin{abstract}
Reports of Ebola outbreaks in affected communities have been associated with rumors, fear, poor perception on the disease and stigmatization of Ebola survivors in their host communities. The depth of knowledge of Ebola Viral disease (EVD) among community members will influence the making of informed decision regarding risky behavioral practices and attitude to survivors. This study was a cross-sectional study using multistage sampling technique to select a total of 1190 respondents from the two area councils of the Federal Capital Territory, Nigeria. Pre-tested questionnaire with 10-point knowledge score on Ebola, 10 point attitude, 6 point scale on practice and 5 point scale on perception was administered by trained interviewers to respondents. Mean age of respondents was 29.61 \pm 7.51years. 97.3\% were aware of EVD. Media (81.7\%) was respondent's first source of information on EVD and the most trusted (80.4\%). Majority (82.1\%) of the respondents had good knowledge of EVD. A good number (83.3\%) also showed poor attitude to survivors of Ebola while thirty-eight (3.2\%) of respondents had poor practice towards EVD prevention. About $96.3 \%$ of respondents had a high perception score. Although Knowledge of Ebola was high, media campaigns needs to be structured and targeted to meet gaps in attitude so as to avoid stigmatization and its attendant consequences by host communities towards Ebola survivors.
\end{abstract}

Keywords: Ebola Virus Disease, Risk Perception, Practice, Attitude, Nigeria

\section{Introduction}

Ebola epidemic of 2014-2016 has been confirmed to be the largest outbreak of the disease in history with a total of 28,616 confirmed, probable and suspected cases and 11,310 confirmed deaths as of April 13, 2016 [1]. The World Health Organization (WHO) reported that cultural belief and behavioral practices, migration across porous borders, damaged public health infrastructure, limited knowledge, shortage of health care workers, community resistance due to fear and misconception among others have contributed to the spread of the disease [2]. Unfortunately, as is frequently reported during outbreaks, communities are the most affected with attendant consequences such as fear, stigmatization, risky behavior and practices. Knowledge, attitude and Perception (KAP) studies are tailored to understand human responses with the benefit of using quantifiable data, generalization of sample size and succinct result [3]. They also complement epidemiological data and provide evidence for targeted interventions especially when conducted early in an epidemic [4]. KAP studies helps to prioritize risk communication efforts so as to accommodate changing cultural norms. Although 
several KAP research has been conducted among cohort of health care workers, secondary school students, traditional healers and mortuary workers in Nigeria and other countries such as Ethiopia, Guinea, and Sierra Leone, there is inadequate research conducted among people living within the communities in Nigeria. [4, 5-11]

Nigeria was declared Ebola virus disease (EVD) free on October 20, 2014 after an acutely ill traveler imported the disease into the country on July 20, 2014 and following intense efforts at rapid containment and eradication $[12,13]$. The country had a total of 20 suspected cases and 8 deaths that were reported $[12,13]$. Nigeria remains at risk of spread of Ebola and other rapidly spreading infectious disease through increasing international travel, inadequate surveillance activities, porous borders and poor medical services $[14,15]$. The Nigerian Federal Government through its Health Ministry instituted an active disease surveillance programme during the outbreak between July and September 2014 including retrospective contact tracing, direct follow up of suspected cases, and review of hospital and dispensary logs and interviewing of health care personnel [16]. Multi-stakeholder groups were involved and educated on the prevention and control methods to rapidly curtail the spread of the disease. These included but were not limited to the utilization of mass media, social media, direct community engagement, targeted messages by environmental and health personnel to prevent fear, stigmatization, anxiety, psychosocial trauma and isolation community ostracism [16]. In the event of infection, community members were advised to report cases promptly to the nearest hospital or the surveillance team. Individuals exposed to infection are to be quarantined and released if asymptomatic after 21 days [17]. Treatment centers were also put in place to provide better patient care for infected persons in the infected states of Lagos and Rivers with intensified awareness- sensitization campaigns in relevant hospitals. Following confirmation of outbreaks in Lagos, affected communities were gripped with palpable anxiety, panic and rumors, and certain non-empirical ethno-medical practices prevailed with stigmatization of convalescent individuals [16]. To understand community perception and the depth of knowledge on EVD, surveys have been conducted in some African countries like DRC Guinea, Congo, Uganda, Ghana, Sudan and Sierra Leone [4, 18-23] which revealed poor depth of knowledge of the disease, prevalence of cultural practices like unsafe burial practices and risky behaviors. These identified issues have influenced and were linked with several reported cases of reoccurring epidemics, and exacerbated morbidity and mortality in those communities $[18,19]$. Elsewhere in the world, poor perceptions with irrational fears regarding EVD was observed in Italy and New Zealand $[18,24]$, while a study conducted in the United States highlighted the need for accurate health information through the internet as major source of information [25]. Level of knowledge changes as health education and community sensitization intensifies. For example, a study conducted post Ebola outbreak reported satisfactory level of knowledge at $92 \%$ compared to studies conducted during the Ebola outbreak reporting low level of knowledge [21, 26, 27]. Community misconceptions is a relatively common occurrence especially in African settings. For example, a national survey conducted in Sierra Leone showed the belief that Ebola can be treated with salt and hot water (41\%), another study reported fear of participants calling the national hotline with the belief that it would result in his or her death [4, 28]. Another study conducted in Guinea found several misconceptions among which include the belief of bathing in salty water to prevent EVD [27]. Discriminatory attitude was rife at $95 \%$ in a study from Sierra Leone [4]. Research has shown strong evidence that individuals become motivated to adopt behavioral change especially when they perceive themselves at risk of infection [4]. Limitation to these community KAP studies include low generalizability due to small study areas and were constrained by time and resources [4, 27]. In Nigeria, there is dearth of data on community KAP study specifically post outbreak to assess the impact of interventions. Moreover, the significance of research to access behavioral change post Ebola outbreak is unknown. It is imperative we provide evidence as to the evolving level of knowledge post EVD campaign and evidence based data for continued intervention especially for major cities such as Abuja, Nigeria's' capital which is fast becoming a connecting hub for international travel. The community KAP study found in Nigeria was conducted during the height of the outbreak in 2014. It provided baseline data on what is known about the disease, it's study limitations was low sampling coverage in terms of number of LGAs and sample size [26].

Against this background and the contained outbreaks in Nigeria, this knowledge, attitude, practices and perception (KAPP) study was conducted immediately after the outbreak (18th May, 2015-20th July, 2015) in selected administrative councils (Bwari and Abuja municipal area councils) in the Federal Capital Territory (FCT), Abuja, Nigeria. Because EVD of 2014 was a new infection in Nigeria, there is dearth of literature on the knowledge and perception of EVD among community members in Nigeria. It is expected that the findings in this study will provide valuable baseline information on knowledge, perception and behavioral risk factors on EVD in the FCT specifically and in Nigeria in general. Targeted messages can be developed to fix knowledge gaps in the community and outcomes may provide basis for the development of recommendations to prevent future outbreak and possibly modify community perception/behavior.

\section{Methods}

\subsection{Study Area and Design}

The Federal Capital Territory (FCT), Nigeria's administrative capital has an estimated human population of 3,195,100 based on 2015 estimates and six area councils (Abuja Municipal Area Council (AMAC), Gwagwalada, 
Abaji, Kuje, Bwari, and Kwali). It is one of the fastest developing cities in Africa with huge influx of people from within and outside the country on daily basis. This is a cross sectional study design conducted in Bwari and AMAC areas councils of FCT.

\subsubsection{Study Period}

This study was conducted from the 18th May, 2015- 20th July, 2015.

\subsubsection{Participants and Sampling}

Using the formula for single proportion $(Z \alpha 2 p(1-p) / d 2)$, the sample size was calculated assuming that $50 \%$ of the population would have poor knowledge and perception of EVD [26], with 97\% level of confidence, an allowable error rate of $3 \%$ and $10 \%$ non-response rate [29]. For this research, a community based cross-sectional interview was administered to participants in randomly selected communities in AMAC and Bwari Area Council using a multi stage sampling method. The eligibility criteria for participation include: (A) respondents can be of any gender (male or female) but must be adult $\geq 18$ years; (B) he/she must have resided in the selected communities for at least six months prior to the onset of the study. In the first stage, AMAC and Bwari Area Council were randomly selected from the 6 councils by simple random sampling and in the second stage, five (5) and six (6) out of 10 and 12 wards were randomly selected by balloting from Bwari and Abuja Municipal Area councils. Using simple balloting, two (2) communities per ward in AMAC and one (1) per ward in Bwari were selected making a total of 17 communities. Per community, a total of 70 households were selected and using abstract transect and a simple bottle spin, data sampling direction was chosen randomly Every 2nd household was chosen until the required number 70 was reached. In each selected household, one respondent who met the inclusion criteria was randomly selected for participation by balloting. In total, a sample size of 1190 was obtained.

\subsection{Questionnaire and Study Outcomes Determination}

Following a review of available literature, a questionnaire consisting of 40 structured questions was prepared and organized into five sections viz: (A) Socio-demographic details of the respondents. (B) Awareness and Knowledge of EVD. (C) Attitude to EVD cases and infected persons. (D) Practice of community members to EVD prevention (E) Risk perception. Knowledge of EVD was assessed using a devised 6 (six) item questions ranging from agent and symptoms of EVD to mode of transmission and prevention of EVD (See supplementary materials F). The questionnaire was pretested using $10 \%$ of the sample size in Nassarawa State and based on the responses, it was adjusted for clarity, consistency, validity and cultural acceptability before its final administration. Knowledge of EVD was assessed using a 6-item scoring system on basic information about the causative agent, symptom, route of transmission, treatment, prevention and control of the disease. The questions included single and multiple type responses and each correct and incorrect responses were scored 1 and 0 point respectively. An overall knowledge score was calculated using cumulative scores for each correct response with a highest achievable knowledge score of 10 . To carry out logistic regression analysis, the cumulative scores were divided into binary groups viz: 0 to $\leq$ 5 was graded as 'poor' knowledge " 0 ", while a score of $\geq 5$ to ten was scored as 'good' knowledge " 1 " based on previous study [30]. The Attitude was assessed using a 10-item scoring system and included the beliefs of the respondents on the isolation of patient, stigmatization of convalescent individuals, and community perception about the disease. Similar scoring criteria for the knowledge score was engaged for these attitude scores.

Practices of community members that may aggravate or prevent EVD was graded by assigning Likert scales scores on a scale of 0-2 points: 2 points for "Always", 1 point for "Sometimes" and 0 points for "Never" as appropriate. Overall practice score was calculated cumulatively with a highest achievable score of 14. Logistic regression was conducted with a grouping of $<7$ as poor practice and $>7$ as good practice. The risk perception scores were based on a 5-item scoring system. It covered respondents' personal risk status (susceptibility), perception of EVD fatality (severity) and perception of morbidity (dread). Risk perception responses were separated into two categories viz: High risk and low risk perception with top box responses scored 1 point and low box responses scored 0 point. The sum for each question on the perception scale was then calculated to obtain the individual aggregate risk perception score similar to in previous studies [31].

\subsection{Interview Procedure}

Data collectors who can speak local dialect (Gwari and Hausa) were employed. Three (3) data collectors were trained for a day. Data collectors approached respondents in the evenings between the hours of $4-7 \mathrm{pm}$ to ensure they would be at home. After explaining the purpose of the survey, and respondents understood the study procedure, informed consent was provided prior to administering the questionnaire. Trained data collectors read out each question to the respondent to ensure all sections are filled and also read the versions translated to local languages for respondents unable to communicate in English. It took data collectors an average of 40-60 minutes to administer a questionnaire.

\subsection{Statistical Analysis}

Consistency of data was done by checking for outliers, duplicates and missing data, and the number of missing values was below $5 \%$ in the responses. Data was entered into and filtered in Microsoft Excel ${ }^{\circledR}$ before they were imported into the SPSS version 17.0 for analysis. Two data clerks performed data consistency by randomly checking for values in data files and running answers using different software platforms for possible errors. Data was analyzed for descriptive and results were presented as proportions and means. Analytical statistical test 
was done using chi square and logistic regression with the level of significance set at $\mathrm{P}<0.05$. The association between knowledge of Ebola viral disease and Socio-demographic variables was determined using chi-square.

\subsection{Ethical Consideration}

This study was approved by the health research ethics committee of the Federal Capital Territory. Abuja, Nigeria with approval number FHREC/2015/01/26/18-05-15. Informed consent were obtained from all participants prior to the administration of questionnaire. Participants were identified using unique number to ensure confidentiality.

\section{Result}

\subsection{Respondents' Characteristics}

The demographic information of the respondents is presented below. A total of 1190 respondents participated in this study including 573 males $(48.2 \%)$ and 617 females (51.8\%). The mean age was $29.61 \pm 7.51$ years (range: $18-$ 70 years). Respondents with tertiary education were $80.4 \%$ and students/job seekers and retirees formed approximately $43.6 \%$ of all occupation categories among the respondents (Table 1).

Table 1. Socio-Demographic Characteristics of Respondents " $N=1190 ”$.

\begin{tabular}{ll}
\hline Respondent characteristics & Number (\%) \\
\hline Age in years & \\
$<25$ & $403(33.9)$ \\
$26-35$ & $562(47.2)$ \\
$36-45$ & $176(14.8)$ \\
$\geq 46$ & $49(4.1)$ \\
Gender & \\
Male & $573(48.2)$ \\
Female & $617(51.8)$ \\
Marital status & \\
Married & $395(33.4)$ \\
Single & $770(65.0)$ \\
Separated & $10(0.8)$ \\
Divorced & $9(0.8)$ \\
Missing & $6(0.5)$ \\
Religion & \\
Christian & $850(71.5)$ \\
Islam & $326(27.4)$ \\
Traditional & $13(1.1)$ \\
Level of education & \\
No formal education & $18(1.5)$ \\
Primary & $37(3.1)$ \\
Secondary & $177(14.9)$ \\
Tertiary & $954(80.4)$ \\
Missing & $4(0.3)$ \\
Occupation & \\
Traders/Farmers/Private business & $344(29.0)$ \\
Student/Retired/Job Applicant & $518(43.6)$ \\
Government employee/Doctor & $326(27.4)$ \\
House hold size & \\
1-3 & $193(16.2)$ \\
6-5 & $147(12.4)$ \\
\hline
\end{tabular}

\subsection{Awareness and Knowledge of Ebola Virus Disease}

Approximately $97.4 \%$ of respondents have heard of Ebola while the media was their primary source of information on EVD $(81.7 \%)$ and was also mentioned as the most trusted source $(80.4 \%)$. A total of $82.5 \%$ of the respondents recognized that virus -was the cause of the disease while $8.3 \%$ and $5.0 \%$ erroneously suggested that the etiology was bacteria and parasite respectively. Furthermore, $3.5 \%$ suggested evil spirit while $7.5 \%$ had no knowledge of the cause. Of the total respondents, $9.4 \%$ believed that Ebola was caused by multiple sources (Table 2). With regards to symptoms, mode of transmission and control, fever ranked the highest (76.9\%) followed by bleeding from the nose $(54.5 \%)$ while the least mentioned common symptom was redness of the eyes (33.0\%), unfortunately over $6 \%$ don't know any of the symptoms. The most frequently mentioned mode of transmission is through eating of bush meat $(84.4 \%)$, but about one tenth mentioned through air (11.8\%) (Table 1). More than half of the respondents were aware of critical means of control including: isolation of an infected individual $(65.7 \%)$ but vaccination against EVD was also mentioned by $49.4 \%$ of all respondents. In addition, $32.4 \%$ opined that embalming infected corpses may control the disease. Huge proportion $(88.6 \%)$ of the respondents were aware that doctors treat EVD while $9.7 \%$ and $4.7 \%$ of the respondents have preference for spiritual healers and traditional healers (Table 2). Most common mode of prevention known within communities were frequent washing of hands $(83.9 \%)$, prayers $(23.0 \%)$, eating bitter kolanut $(15.5 \%)$, while the least mentioned was bathing with salt water frequently $(6.5 \%)$ (Table 2$)$.

Table 2. Knowledge of Ebola Virus Disease.

\begin{tabular}{ll}
\hline Respondents characteristics & Number (\%) \\
\hline Heard of Ebola & $1159(97.4)$ \\
Yes & $31(2.6)$ \\
No & \\
Cause & $99(8.3)$ \\
Bacteria & $982(82.5)$ \\
Virus & $59(5.0)$ \\
Parasite & $42(3.5)$ \\
Evil spirit & $89(7.5)$ \\
Don't know & \\
Symptom & $383(33.0)$ \\
Red eyes & $915(76.9)$ \\
Fever & $649(54.5)$ \\
Bleeding from the nose & $78(6.6)$ \\
Don't know & \\
Mode of transmission & $1004(84.4)$ \\
Eating bush meat & $423(35.5)$ \\
Breast milk of an infected individual & $141(11.8)$ \\
Air & $68(5.7)$ \\
Don't know & \\
Control & $378(31.8)$ \\
Building a separate latrine for sick individual & $782(65.7)$ \\
Isolate infected individual & $386(32.4)$ \\
Embalming infected corpse & $588(49.4)$ \\
Vaccinating against Ebola virus disease & $56(4.7)$ \\
Treatment & $115(9.7)$ \\
Traditional healer & $1054(88.6)$ \\
Spiritual healer & \\
Doctor & \\
\hline & \\
\hline
\end{tabular}




\begin{tabular}{ll}
\hline Respondents characteristics & Number (\%) \\
\hline Don't know & $71(6.0)$ \\
Prevention & \\
Bathing with salt water frequently & $77(6.5)$ \\
Eating bitter kolanut & $185(15.5)$ \\
Washing hands frequently & $999(83.9)$ \\
Drinking salt water & $29(2.4)$ \\
Prayers & $274(23.0)$ \\
\hline
\end{tabular}

The analysis of knowledge regarding signs and symptoms indicated that $82.5 \%$ of respondents were able to correctly identify the cause of Ebola. A huge number of respondents $93.4 \%$ could correctly identify symptoms. Overall, majority of the respondents $(82.1 \%)$ had good general knowledge of EVD (Table 3).

Table 3. Respondents with Satisfactory knowledge by gender.

\begin{tabular}{|c|c|c|c|c|}
\hline Gender & Causes of Ebola n (\%) & Symptoms n (\%) & Preventive measures n (\%) & General Knowledge n (\%) \\
\hline Male $(n=573)$ & $483(40.6)$ & $533(44.7)$ & $468(39.9)$ & $478(40.2)$ \\
\hline Female $(n=617)$ & $498(41.9)$ & $579(48.6)$ & $531(45.3)$ & 499 (41.9) \\
\hline All respondents $(n=1190)$ & $981(82.5)$ & $1112(93.4)$ & $999(85.2)$ & $977(82.1)$ \\
\hline
\end{tabular}

\subsection{Association Between Respondents' Characteristics and Knowledge of Ebola Virus Disease}

There was an association between certain variables and the level of knowledge of EVD. More Bwari Area Council respondents had better knowledge of EVD compared with residents from AMAC $\left(\chi^{2}=12.91, \quad \mathrm{P}<0.001\right)$. Similarly, significant knowledge difference exists depending on the level of education of respondents $\left(\chi^{2}=4.94, \mathrm{P}<0.05\right)$ and size of households $\left(\chi^{2}=5.06, \mathrm{P}<0.05\right)($ Table 4$)$.

Table 4. Association between respondents' characteristics and knowledge of Ebola virus disease.

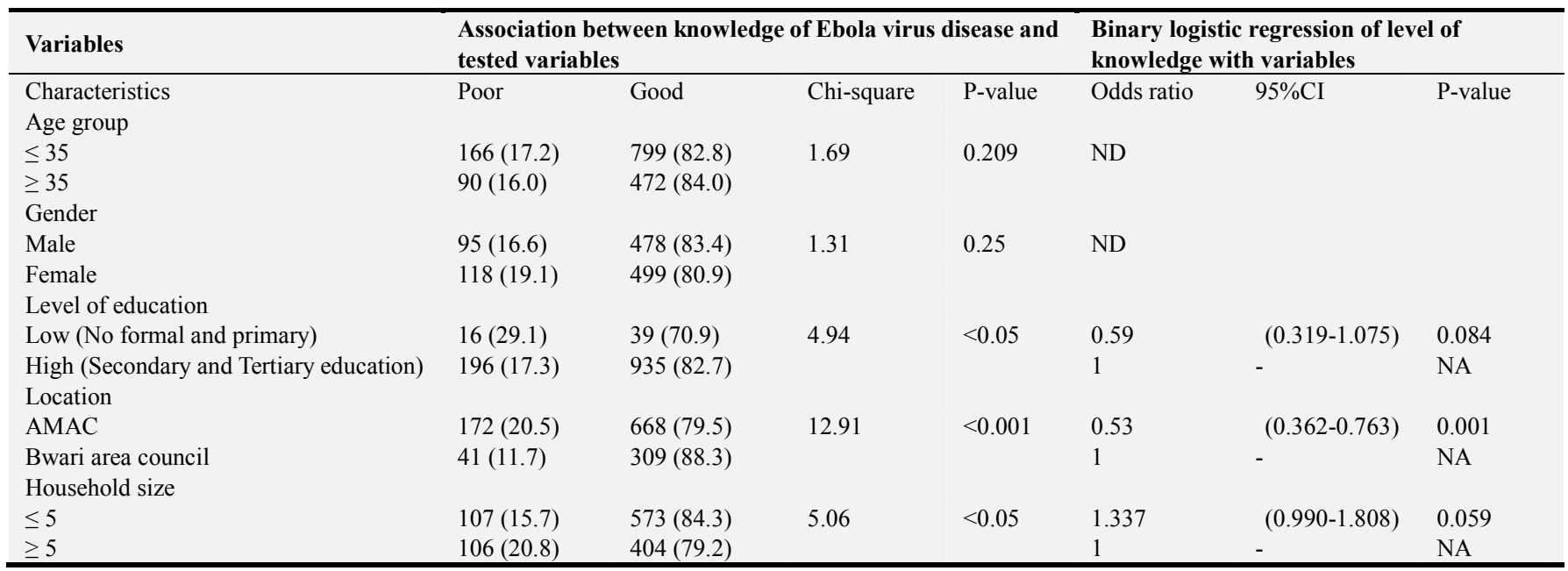

Specifically, the odds of respondents residing in Bwari Area Council to have better knowledge of EVD was two times over than for residents from AMAC $(\mathrm{OR}=0.53$, CI $95 \%=0.36-0.76$, $\mathrm{P}<0.001)$. Respondents with lower level of education were almost twice less likely to have good knowledge of EVD compared with those with higher level of education $(\mathrm{OR}=0.59$, $95 \% \mathrm{CI}=0.32-1.07, \mathrm{P}=0.08$ ). Furthermore, respondents with household size $\leq 51.3$ times were more likely to have better knowledge of EVD than those with $\geq 5$ members of the household $(\mathrm{OR}=1.34, \mathrm{CI} 95 \%=0.99-1.81, \mathrm{P}=0.05)$ (Table 4).

\subsection{Attitude of Community Members to Ebola Virus Disease Recovered Cases}

Majority $(83.3 \%)$ of the respondents had poor attitude to EVD recovered individuals. About $82.3 \%$ of respondents disagreed to take suspected persons to traditional homes with more than half $(50.3 \%)$ refusing to share food and drink with individuals completely recovered from the disease, or to shake hands with them $(38.7 \%)$, or welcome a neighbor fully recovered from EVD back into the community (40.6\%). However more than half $(50.9 \%)$ agreed to attend social functions with completely recovered individuals. Less than one-seventh $(13.3 \%)$ opined that the publicity given to Ebola was unnecessary with $11.6 \%$ of respondents believing it is a punishment from God. About $61.6 \%$ of respondents disagreed that school pupil completely recovered from EVD puts other pupils at risk. Majority $(80.3 \%)$ of the respondents opined that they will not keep the information secret if family member contracts the disease with $2.9 \%$ agree that EVD is a disease affecting only poor people (Table 5).

Table 5. Attitude of community members to EVD recovered cases.

\begin{tabular}{lc}
\hline Variables & Number (\%) \\
\hline $\begin{array}{l}\text { Suspected persons should be taken to traditional homes such as church, mosque, juju shrine } \\
\text { Agree }\end{array}$ & $140(11.8)$ \\
\hline
\end{tabular}




\begin{tabular}{ll}
\hline Variables & Number (\%) \\
\hline Disagree & $979(82.3)$ \\
Undecided & $71(6.0)$ \\
I will not share food and drink with an individual recovered from Ebola viral disease & $599(50.3)$ \\
Agree & $461(38.7)$ \\
Disagree & $130(10.9)$ \\
Undecided & $460(38.7)$ \\
I will not shake hands with an individual who has recovered from Ebola viral disease & $587(49.3)$ \\
Agree & $143(12.0)$ \\
Disagree & \\
Undecided & $606(50.9)$ \\
I can attend social functions/community meetings with an individual recovered from Ebola Viral Disease \\
Agree & $453(38.1)$ \\
Disagree & $131(11.0)$ \\
Undecided & \\
I will welcome a neighbor recovered from Ebola back into the community & $548(46.1)$ \\
Agree & $483(40.6)$ \\
Disagree & $159(13.4)$ \\
Undecided & \\
A school pupil recovered from Ebola puts other pupils in their class at risk & $281(23.6)$ \\
Agree & $733(61.6)$ \\
Disagree & $176(14.8)$ \\
Undecided & \\
I will keep the information secret if a family member contracts Ebola & $106(8.9)$ \\
Agree & $955(80.3)$ \\
Disagree & $129(10.8)$ \\
Undecided &
\end{tabular}

\subsection{Association Between Respondents' Characteristics and Community Attitude to Ebola Virus Disease Recovered Cases}

Table 6. Association between Respondents' characteristics and Attitude to EVD recovered case.

\begin{tabular}{|c|c|c|c|c|c|c|c|}
\hline \multirow{2}{*}{$\begin{array}{l}\text { Variables } \\
\text { Characteristics }\end{array}$} & \multicolumn{4}{|c|}{$\begin{array}{l}\text { Association between attitude to Ebola virus disease and } \\
\text { tested variables }\end{array}$} & \multicolumn{3}{|c|}{$\begin{array}{l}\text { Binary logistic regression of level of } \\
\text { knowledge with variables }\end{array}$} \\
\hline & Unfavorable & Favorable & Chi-square & P-value & Odds ratio & 95\%CI & P-value \\
\hline \multicolumn{8}{|l|}{ Age group } \\
\hline$\geq 35$ & $176(17.8)$ & $49(24.6)$ & 5.09 & 0.024 & 1 & $(0.983-2.042)$ & NA \\
\hline \multicolumn{8}{|l|}{ Level of education } \\
\hline Low (No formal and primary) & $8(4.0)$ & $47(4.8)$ & 0199 & 0662 & & & \\
\hline \multicolumn{8}{|l|}{ Location } \\
\hline AMAC & $703(70.9)$ & $137(68.8)$ & 0350 & 0554 & ND & & \\
\hline Bwari area council & $288(29.1)$ & $62(31.2)$ & 0.550 & 0.554 & ND & & \\
\hline \multicolumn{8}{|l|}{ Household size } \\
\hline$\leq 5$ & $585(59.0)$ & $95(47.7)$ & 8620 & 0003 & 1.521 & $(1.117-2.071)$ & 0.008 \\
\hline$\geq 5$ & $406(41.0)$ & $104(52.3)$ & 0.029 & 0.003 & 1 & & NA \\
\hline
\end{tabular}

Table 6 shows the association between respondents' characteristics and community Attitude to EVD recovered cases.

Respondents younger than 35 years old were 1.42 times more likely to have favorable attitude than those older than 35 $(\mathrm{OR}=1.42, \quad 95 \% \quad \mathrm{CI}=0.98 \quad-2.04, \quad \mathrm{P}=0.06)$. Similarly, respondents with household sizes lower than 5 were 1.5 times more likely to have better attitude to EVD recovered individuals than those with household sizes greater than 5 . $(\mathrm{OR}=1.52,95 \% \mathrm{CI}=1.12-2.07, \mathrm{P}<0.005)$.

\subsection{Practices of Community Members towards Ebola Virus Disease Prevention}

Thirty-eight $(3.2 \%)$ of respondents have poor practice towards EVD prevention. Regular washing of hands with soap and water was reported by $94.8 \%$ of respondent. A minority $8.6 \%$ claimed to always bath with salt and water. Regarding avoiding burial practices of an individual that died of Ebola, less than a quarter $(20.3 \%)$ respondents admitted they will not avoid it (Table 7).

Table 7. Practices of community members towards EVD prevention.

\begin{tabular}{ll}
\hline Variables & Number (\%) \\
\hline Wash hands with soap and water & $1128(94.8)$ \\
Always & $58(4.9)$ \\
Sometimes & $4(0.3)$ \\
Never & \\
\hline
\end{tabular}




\begin{tabular}{ll}
\hline Variables & Number (\%) \\
\hline Bath with salt and water & $102(8.6)$ \\
Always & $350(29.4)$ \\
Sometimes & $738(62.0)$ \\
Never & \\
Avoid burial ritual of someone who died of Ebola & $801(67.4)$ \\
Always & $147(12.4)$ \\
Sometimes & $241(20.3)$ \\
Never & \\
Overall Practice & $38(3.2)$ \\
Poor & $1152(96.8)$ \\
Good & \\
\hline
\end{tabular}

\subsection{Binary Logistic Regression for Respondents' Characteristic and Community Practices on Ebola Virus Disease Prevention}

Respondents living within AMAC were 3 times more likely to have good practices regarding EVD prevention than those living within Bwari $(\mathrm{OR}=3.301, \mathrm{CI}=1.652-6.593, \mathrm{P}<0.001)$ to a significant level (Table 8).

Table 8. Binary logistic regression for respondents' characteristic and community practices on EVD prevention.

\begin{tabular}{|c|c|c|c|c|c|c|c|}
\hline \multirow{2}{*}{$\begin{array}{l}\text { Variables } \\
\text { Characteristics }\end{array}$} & \multicolumn{4}{|c|}{$\begin{array}{l}\text { Association between practices on Ebola virus disease } \\
\text { and tested variables }\end{array}$} & \multicolumn{3}{|c|}{$\begin{array}{l}\text { Binary logistic regression on community } \\
\text { practices on EVD prevention. }\end{array}$} \\
\hline & Poor & Good & Chi-square & P-value & Odds ratio & $95 \%$ CI & P-value \\
\hline \multicolumn{8}{|l|}{ Age group } \\
\hline$\leq 35$ & $34(2.9)$ & $931(78.2)$ & \multirow{2}{*}{1.79} & \multirow{3}{*}{0.180} & \multirow{3}{*}{ ND } & & \\
\hline$\geq 35$ & $4(0.3)$ & $221(18.6)$ & & & & & \\
\hline \multicolumn{6}{|l|}{ Gender } & & \\
\hline Male & $30(78.9)$ & $543(47.1)$ & \multirow{3}{*}{14.91} & \multirow{3}{*}{0.000} & \multirow{3}{*}{$\begin{array}{l}0.325 \\
1\end{array}$} & \multirow{3}{*}{$(0.144-0.733)$} & \multirow{3}{*}{$\begin{array}{l}0.007 \\
\text { NA }\end{array}$} \\
\hline Female & $8(21.1)$ & $609(52.9)$ & & & & & \\
\hline Level of Education & & & & & & & \\
\hline Low (No formal and primary) & $2(5.3)$ & $53(4.6)$ & \multirow{3}{*}{0.035} & \multirow{3}{*}{0.852} & \multirow{3}{*}{ ND } & & \\
\hline High (Secondary and Tertiary education) & $36(94.7)$ & $1095(95.4)$ & & & & & \\
\hline \multicolumn{5}{|l|}{ Location } & & & \\
\hline AMAC & $14(36.8)$ & $826(71.7)$ & \multirow{3}{*}{21.531} & \multirow{3}{*}{0.000} & \multirow{3}{*}{3.301} & \multirow{2}{*}{$(1.652-6.593)$} & \multirow{2}{*}{0.001} \\
\hline Bwari area council & $24(63.2)$ & $326(28.3)$ & & & & & \\
\hline \multicolumn{5}{|l|}{ Household size } & & & \\
\hline$\leq 5$ & $19(50.0)$ & $661(57.4)$ & \multirow{2}{*}{0.818} & \multirow{2}{*}{0.366} & \multirow{2}{*}{ ND } & & \\
\hline$\geq 5$ & $19(50.0)$ & $491(42.6)$ & & & & & \\
\hline
\end{tabular}

\subsection{Risk Perception of Respondents on Ebola Virus Disease}

About $96.3 \%$ of respondents have a high perception score. Less than half of the respondents $(48.7 \%)$ perceive that the severity of the consequences of Ebola is very serious. About $22.9 \%$ of respondents worry about contracting Ebola. More than half of respondents $(60.5 \%)$ believe that Ebola is a killer disease (Table 9).

Table 9. Perception of community members towards EVD prevention

\begin{tabular}{lc}
\hline Variables & Number (\%) \\
\hline Perceived Severity of Consequence of Ebola Viral Disease \\
\hline Not serious & $56(4.7)$ \\
Somewhat serious & $56(4.7)$ \\
Undecided & $163(13.7)$ \\
Serious & $336(28.2)$ \\
Very serious & $579(48.7)$ \\
Fear/ worry about contracting Ebola Viral Disease & \\
Not at all & $137(11.5)$ \\
Rarely & $188(15.8)$ \\
Undecided & $126(10.6)$ \\
From time to time & $466(39.2)$ \\
A great deal & $273(22.9)$ \\
\hline
\end{tabular}

\begin{tabular}{lc}
\hline Variables & Number (\%) \\
\hline \multicolumn{2}{l}{ Perceived Severity of Consequence of Ebola Viral Disease } \\
\hline Ebola is a killer disease & $720(60.5)$ \\
Strongly agree & $357(30.0)$ \\
Agree & $65(5.5)$ \\
Undecided & $23(1.9)$ \\
Disagree & $25(2.1)$ \\
Strongly disagree & $44(3.7)$ \\
Do you agree that a corpse that died due to Ebola is nonger contagious \\
Strongly agree & $93(7.8)$ \\
Agree & $97(8.2)$ \\
Undecided & $357(30.0)$ \\
Disagree & $599(50.3)$ \\
\hline
\end{tabular}

\section{Discussion}

The outbreak of Ebola virus in Nigeria in 2014 left several communities which were affected in fear, anxiety and panic. Reports of stigmatization of convalescent individuals were also reported from affected communities. This situation is largely attributed to the poor knowledge of the disease, attitude of community members and several cultural practices.

This study revealed age, household size, location and level 
of education as influencing factors of knowledge, attitude and practice. The national bureau of economic research has shown an association between education and health. The greater the level of education, the more health seeking behavior [32]. In this study, majority of respondents $(82.1 \%)$ had good level of knowledge of EVD. Smaller household size, location (satellite area) and higher educational status has been shown as predictors of good level of knowledge in this study. The reason for these predictors could be that smaller house hold size and people with higher educational status have been exposed to increased source of information on EVD. Moreover previous studies have shown that level of knowledge of people have been affected by their educational status [26]. Also this study revealed that respondents from Bwari area council, a satellite town had higher levels of knowledge than AMAC, this difference although unable to be interpreted from the current data is probably attributed to increased community education than in the more urbanized AMAC area. Most of the respondents (97.4\%) were aware of Ebola Virus disease (EVD). This is similar to several community studies conducted in Sierra Leone which showed high awareness to the Ebola virus [4, 22, 33]. This high awareness could be attributed to the several campaigns carried out during the outbreak. The media was reported in this study as the most trusted source of information on EVD which corresponds to several reports in Sierra Leone [4, 22, 33]. This route of information dissemination should be maximally exploited to target and educate the community on Ebola and other viral infectious diseases since it's the widely reported means of obtaining information [15, 34]. Efforts should be made to reach and enlighten community members who are less educated. Pamphlets and jingles in local languages that are easily understood should be used. Ebola virus disease has no vaccine [12], however $49.4 \%$ of respondents in this study opined that Ebola can be vaccinated against. Several misleading reports on social media during the outbreak may be attributed to this. It is alarming that $32.4 \%$ of respondents in this study mentioned embalming as a means of controlling EVD. This practice may increase the risk of infection of more individuals. WHO has set clear guidelines on the proper burial of an individual that died from EVD [35]. This prevalent cultural practice has exacerbated the transmission of the disease in West Africa [15, 19, 36]. A WHO report in 2015 highlighted that $60 \%$ and $80 \%$ of new infections in Guinea and Sierra Leone respectively was attributed to burial practices [2]. Community members should be properly educated on the risk involved with practices such as corpse embalmment.

This study reported poor attitude $(83.3 \%)$ to EVD recovered individuals which is similar to the studies conducted in Sierra Leone [4, 33]. Stigmatization is still a strong factor and it is imperative that social mobilization messages are tailored in educating the community to control this trend $[15,19,37]$. This study revealed that respondents who were younger $(\leq 35)$ are more likely to have good attitude to EVD convalescent individuals. This differs from a finding conducted among secondary school students in Nigeria were the older age group were likely to have better preventive measures [38]. Although, the reason for this age difference was not clear, the younger age group has been observed to display improved social interactions and less fear of contracting EVD [39]. Although $82.3 \%$ of respondents in this study agree that suspected persons with EVD should not be taken to traditional healing homes, $11.8 \%$ supported the idea. This route of treatment has been a long time practice in Africa where access to health facilities especially in the rural and poor communities are limited [2].

Regarding community practice, regular washing of hands with soap and water was practiced by majority of the respondents in Abuja (94.8\%), similarly to what was observed in Lagos, Nigeria [15]. To curtail the spread of the infection in hospitals, schools, work environment and even individuals, we encourage individuals to use hand sanitizers more frequently. An alarming high percentage (71\%) of respondents in this study said they cook the dead remains of bush animals. Bush meat eating is a common practice in several communities across Nigeria. This must be strongly discouraged as Ebola has been known to be transmitted in countries prevalent with such harmful practice [1]. The practice of bathing with salt and water, and eating bush meat is still being practiced by $8.6 \%$ and $8.2 \%$ of the respondents respectively in this study. This observation is similar to that observed in Lagos, Nigeria with $6 \%$ of the respondents still bathing with salt and water [15]. There was a high risk perception reported among respondents to EVD in this study which may be due to the media campaigns regarding the disease. Several jingles on television, radio and newspaper helped in making information available to the public. This data also corroborated the findings in Sierra Leone [33]. Studies have shown that people have a higher perception when they experience disease outbreak [40]. This probably explains the high risk perception among the respondents in this study.

This study was conducted in two areas councils of the FCT and as is limited by sampling coverage due to the number of area councils sampled ( 2 out of 6 area councils). In addition, this study might be subject to recall bias and is dependent on respondents' ability to recall and to answer honestly. Due to the awareness post Ebola outbreak in the country, it is possible that respondents provided socially desirable responses therefore self-reported behavior might not reflect realities. However, this KAP study provides invaluable data on addressing gaps post Ebola campaign and for promoting behavioral change in communities.

\section{Conclusion}

Findings from this study necessitate the need for sustained media campaigns with focus on preventive measures aimed at promoting safe burial, addressing myths and misconceptions regarding EVD such as bathing with salt and water. We recommend behavioral change campaign messages that will promote healthy behavior of community members towards stigmatizing convalescent individuals. The media such as radio and television should be used as a medium of communication. 


\section{Acknowledgements}

The authors wish to acknowledge Prof Geoffery Fosgate of the Department of Production Animal studies, Faculty of Veterinary Sciences, University of Pretoria for his contributions in the manuscript development.

\section{References}

[1] World Health Organization. (2016). Special report after Ebola in West Africa - unpredictable risks, preventable epidemics. The New England Journal of Medicine, 6: 587-596.

[2] WHO. (2015). Factors that contributed to undetected spread of the Ebola virus and impeded rapid containment [Internet]. World Health Organization; [cited 2018 Jul 6]. Available from: http://www.who.int/csr/disease/ebola/one-year-report/factors/e $\mathrm{n} /$.

[3] Idris, B. J., Inem, V., and Balogun, M. (2015). Comparing the knowledge, attitude and practices of health care workers in public and private primary care facilities in Lagos State on Ebola virus disease. Pan African Medical Journal, 22: 19.

[4] Jalloh, M. F., Sengeh, P., Monasch, R., Jalloh, M. B., DeLuca, N., Dyson, M., Golfa, S,. Sakurai, Y,. Conteh, L,. Sesay, S, Brown, V.. Li, W.. Mermin, J.. Bunnel, R.. (2017). National survey of Ebola-related knowledge, attitudes and practices before the outbreak peak in Sierra Leone. BMJ Global Health. BMJ Publishing Group, Vol. 2, August 2014.

[5] Iliyasu, G., Ogoina, D., Out, A. A., Dayyab, F. M., Ebenso, B., Otokpa, D., Rotifa, S., Olomo, W. T., Habib, A. G. (2015). A multi-site knowledge attitude and practice survey of Ebola virus disease in Nigeria. PLoS One, 10 (8). Aug 28.

[6] Onowhakpor, A. O., Adam, V. Y., Sakpa, O. E., Ozokwelu, L. U. (2018). Status of Ebola virus disease (EVD) preventive practices among health care workers (HCWs) in Benin city: A year after disease containment in Nigeria. Pan African Medical Journal, 30.

[7] Ilesanmi, O., Alele, F. O. (2014). Knowledge, attitude and perception of Ebola virus disease among secondary school students in Ondo State, Nigeria, October. PLoS Current, 2016; 8 .

[8] Helen, A., Dairo, M. (2016). Ebola virus disease: risk perception and gaps in compliance with infection control practices among mortuary workers in two south western cities of Nigeria. International Journal of Tropical Disease and Health, Jan 10; 17 (1): 1-9.

[9] Abebe, T. B., Bhagavathula, A. S., Tefera, Y. G., Ahmad, A., Khan, M. U., Belachew, S. A., Brown, B., Abegaz, T. M. (2016). Healthcare professionals' awareness, knowledge, attitudes, perceptions and beliefs about Ebola at Gondar University hospital, Northwest Ethiopia: A cross-sectional study. Journal of Public Health Africa. Nov 30; 7 (2).

[10] Alioune, C. (2016). Knowledge, attitudes and practices of health care workers on Ebola in hospital towards Ebola virus disease, Conakry, Guinea, Central African Journal Public Health, 2018; 4 (1): 1.

[11] A. T. eacute, F. A. T. eacute, F. B. Sako, A. Delamo, F. S. Tonguino, D. Sylla, M. Bangoura, M. Barry, M. Cisse, and P. Vanhems. (2016). Knowledge, attitudes, and practices of health care workers on Ebola virus disease in Conakry, Guinea: A cross-sectional study. Journal Public Health Epidemiology, 8 (2): $12-6$

[12] Shuaib. F., Gunnala, R., Musa, E. O., Mahoney, F. J., Oguntimehin, O., Nguku, P. M., Nyanti, S. B., Knight, N., Gwarzo, N. S., Idigbe, O., Nasidi, A., Vertefeuile, J. F. (2014). Ebola virus disease outbreak - Nigeria, July-September 2014. Morbidity and Mortality Weekly Report, [Internet]. Oct 3 [cited 2018 Jul 6] 63 (39): 867-72. Available from: http://www.ncbi.nlm.nih.gov/pubmed/25275332.

[13] Fasina, F. O., Shittu, A., Lazarus, D., Tomori, O., Simonsen, L., Viboud, C., Chowel, G. (2014). Transmission dynamics and control of Ebola virus disease outbreak in Nigeria, July to September 2014. European Surveillance. [Internet]. 2014 Oct 9 [cited 2018 Jul 6], 19 (40): 20920. Available from: http://www.ncbi.nlm.nih.gov/pubmed/25323076.

[14] Abiodun, O., Moses, A. O., Musa, A. M., Simeon, A. W., Folakemi, A-O. A., Ojong, O. E., Samuel, S., Patrick, N., Peter, N., Adebola, O., Akin, O., Abdusalami, N. (2016). The role of the laboratory in outbreak investigation of viral haemorrhagic fever in Nigeria, 2014. Pan African Medical Journal [Internet]. 2016 [cited 2018 Jul 6], 23. Available from: $\mathrm{http} / / /$ www.panafrican-med-journal.com/content/article/23/23 3/full/.

[15] Gidado, S., Oladimeji, A. M., Roberts, A. A., Nguku, P., Nwangwu, I. G., Waziri, N. E., Shuaib, F., Oguntimehin, O., Musa, E., Nzuki, C., Nasidi, A., Adewuyi, P., Daniel, T-A., Olayinka, A., Odunabjo, O., Poggensee, G. (2015). Public Knowledge, perception and source of information on Ebola virus disease - Lagos, Nigeria; September, 2014. PLoS Current [Internet]. 2015 Apr 8 [cited 2018 Jul 6], 7. Available from: http://www.ncbi.nlm.nih.gov/pubmed/25914860.

[16] Federal Ministry of Health. Status of Ebola virus disease in Nigeria monday 8th September, 2014 [Internet]. [cited 2018 Jul 6]. Available from: http://www.health.gov.ng/index.php/component/content/article /9-uncategorised/197-status-of-ebola-virus-disease-in-nigeriamonday-8th-september-2014.

[17] Ruparelia, C., Curless, M., Trexler, P., Black, M. (2015). Prevention and control of Ebola virus disease in health care facilities with limited resources.

[18] Petrie, K. J., Faasse, K., Thomas, M. G. (2016). Public perceptions and knowledge of the Ebola virus, willingness to vaccinate, and likely behavioral responses to an outbreak. Disaster Medical Public Health Preparedness. Aug 1; 10 (4): 674-80.

[19] Hewlett, B. S., Amola, R. P. (2003). Cultural contexts of Ebola in northern Uganda. Emerging Infectious Disease, 9 (10): 1242-8. [Internet]. 2003 Oct [cited 2018 Jul 6]; Available from: http://www.ncbi.nlm.nih.gov/pubmed/14609458.

[20] Adongo, P. B., Tabong, P. T. N., Asampong, E., Ansong, J., Robalo, M., Adanu, R. M. (2016). Beyond knowledge and awareness: addressing misconceptions in Ghana's preparation towards an outbreak of Ebola virus disease. PLoS One. 2016; $11(2): 1-20$.

[21] Mohamed, M. M. G, Shwaib, H. M., Fahim, M. M., Ahmed, E. A., Omer, M. K., Monier, I. A., Balla, S. A. (2015). Ebola hemorrhagic fever under scope, view of knowledge, attitude and practice from rural Sudan in 2015. Journal of Infectious Public Health. 2017 May 1; 10 (3): 287-94. 
[22] Jiang, H., Shi, G. Q., Tu, W. X., Zheng, C. J., Lai, X. H., Li, X. X., Wei, Q., Li, M., Deng, L. Q., Huo, X., Chen, M. Q., Xu, F., Ye, L. J., Bai, X. C., Chen, T. N., Yin, S. H., Samba, T. T., Liang, X. F. (2016). Rapid assessment of knowledge, attitudes, practices, and risk perception related to the prevention and control of Ebola virus disease in three communities of Sierra Leone. Infectious Disease Poverty, 5 (1): 53. [Internet]. 2016 Dec 6 [cited 2020 Jan 29]; Available from: http://idpjournal.biomedcentral.com/articles/10.1186/s40249-0 16-0142-9.

[23] Jalloh, M. F., Bunnell, R., Robinson, S., Jalloh, M. B., Barry, A. M., Corker, J., Sengeh, P., Vansteelandt, A., Li, W., Dafae, F., Diallo, A. A., Martel, L. D., Hersey, S., Marston, B., Morgan, O. (2017). Assessments of Ebola knowledge, attitudes and practices in forécariah, Guinea and Kambia, Sierra Leone, july-august 2015. Philosophical Transactions of the Royal Society B: Biological Sciences, 26; 372 (1721).

[24] Prati, G., Pietrantoni, L. (2016). Knowledge, risk perceptions, and xenophobic attitudes: evidence from Italy during the Ebola outbreak. Risk Analysis, 36 (10): 2000-10 [cited 2020 Jan 29]. Available from: http://doi.wiley.com/10.1111/risa.12537.

[25] Rolison, J. J., Hanoch, Y. (2015). Knowledge and risk perceptions of the Ebola virus in the United States. Preventive Medicine Reports, 1 (2): 262-4.

[26] CPP. (2014). Study on the Ebola virus disease (EVD) Knowledge, attitudes and practices of Nigerians in Lagos State. 2014; (September): 1-31. Available from: http://cpparesearch.org/wp-content/uploads/2015/01/Knowled ge-Attitude-Practices-of-Nigerians-on-the-EVD_Survey-Repo rt_2014.pdf.

[27] Buli, B. G., Mayigane, L. N., Oketta, J. F., Soumouk, A., Sandouno, T. E., Camara, B., Toure, M. S., Conde, A. (2015). Misconceptions about Ebola seriously affect the prevention efforts: KAP related to Ebola prevention and treatment in Kouroussa Prefecture, Guinea. Pan African Medical Journal, 22: 11 .

[28] Yamanis, T., Nolan, E., Shepler, S. (2016). Fears and Misperceptions of the Ebola Response System during the 2014-2015 outbreak in Sierra Leone. PLoS Neglected Tropical Disease, 10 (10).

[29] Araoye, M. O. (2003). Research methodology with statistics: for health and social sciences. Nathadex [cited 2018 Jul 6]. Available from: http://www.libonline.bowenuniversity-edu.org:8000/cgi-bin/k oha/opac-detail.pl?biblionumber $=4191$.

[30] Olowookere, S. A., Fatiregun, A. A., Gbolahan, O. O., Adepoju, E. G. (2014). Diagnostic proficiency and reporting of Lassa fever by physicians in Osun State of Nigeria. BMC Infectious Disease, 14 (1): 344 . [cited 2018 Jul 6]. Available from: http://www.ncbi.nlm.nih.gov/pubmed/24950705.
[31] Tabatabaei, S. M., Hassanzehi, A., Pakzad, A., Mohammdi, M., Madani, A. (2014). Factors Influencing Crimean-Congo Hemorrhagic Fever Risk Perceptions in the General Population, Southeast Iran. Internal Journal of Infection, 6; 1 (1). [cited 2018 Jul Available from: http://intjinfection.neoscriber.org/en/articles/14678.html.

[32] Groot, W., van den Brink, H. M. (2007). The effects of education on health. In: human capital: advances in theory and evidence p. 65-80 [cited 2020 Feb 4]. Available from: https://www.nber.org/digest/mar07/w12352.html.

[33] Monasch, R. (2014). Study on Public Knowledge, attitudes, and practices relating to Ebola virus disease (EVD) prevention and medical care in Sierra Leone. Unicef. 2014.

[34] World Health Organization. (2014). Key Messages for Social Mobilization and Community Engagement in Intense Transmission Areas. 2014.

[35] World Health Organization. WHO | How to conduct safe and dignified burial of a patient who has died from suspected or confirmed Ebola virus disease. WHO/EVD/Guidance/Burials/142 [Internet]. 2014; 1 (October): $17 . \quad$ Available from: http://www.who.int/csr/resources/publications/ebola/safe-buri al-protocol/en/.

[36] Nielsen, C. F., Kidd, S., Sillah, A. R. M., Davis, E., Mermin, J., Kilmarx, P. H. (2015). Improving burial practices and cemetery management during an Ebola virus disease epidemic - Sierra Leone, 2014. Morbidity and mortality weekly report, 64 (1): 20-7. 2015 Jan 16 [cited 2018 Jul 6]. Available from: http://www.ncbi.nlm.nih.gov/pubmed/25590682.

[37] Modarres, N. (2015). Community Perspectives about Ebola in Bong, Lofa and Montserrado Counties of Liberia : Results of a Qualitative Study Final Report. Johns Hopkins Center for Communication Programs, 2015.

[38] Ilesanmi, O., Alele, F. O. (2016). Knowledge, attitude and perception of Ebola virus disease among secondary school students in Ondo State, Nigeria, October, 2014. PLoS Current. 2016 [cited 2020 Jan 28]; Available from: https://www.ncbi.nlm.nih.gov/pmc/articles/PMC4866528/.

[39] Ajayi, N. A., Ojide, C. K., Ajayi, I. A., Ukwaja, K. N. (2019). Evaluation of clinicians' knowledge of and attitudes to Ebola virus disease in Ebonyi State, Nigeria. Journal of virus Eradication, 5 (3): 145-51. [cited $2020 \mathrm{Feb} 10$ ] Available from: https://www.ncbi.nlm.nih.gov/pmc/articles/PMC6816123/.

[40] Sullivan, N., Yang, Z-Y., Nabel, G. J. (2003). Ebola virus pathogenesis: implications for vaccines and therapies. Journal of Virology, 77 (18): 9733-7. [cited 2018 Jul 6]. Available from: http://www.ncbi.nlm.nih.gov/pubmed/12941881. 